\title{
HUBUNGAN KEBIJAKAN K3 DENGAN KEPERAWATAN DI INDONESIA
}

\author{
Kiki Dwi Febriyanti
}

\section{Kiifeb83@gmail.com}

\section{LATAR BELAKANG}

RS Umum adalah RS yang memberikan pelayanan kesehatan pada semua bidang dan jenis penyakit. Pelayanan RS merupakan bagian yang tidak terpisah dari sistem pelayanan kesehatan pada umumnya. Dalam pemberian pelayanan kesehatan, $\mathrm{RS}$ diharapkan dapat memberikan pelayanan yang berkualitas. Potensi bahaya di RS dapat disebabkan oleh faktor biologi, faktor kimia, faktor ergonomi, faktor fisik, faktor psikososial, bahaya mekanik, bahaya listrik, limbah RS yang dapat mengancam jiwa dan kehidupan bagi para karyawan RS, pasien maupun para pengunjung yang ada dilingkungan RS yang mengakibatkan penyakit dan kecelakaan akibat kerja.

Kesehatan dan Keselamatan Kerja (K3) merupakan suatu upaya perlindungan kepada tenaga kerja dan orang lain yang memasuki tempat kerja terhadap bahaya dari akibat kecelakaan kerja. Tujuan K3 adalah mencegah, megurangi, bahkan menihilkan resiko penyakit dan kecelakaan akibat kerja (KAK) serta meningkatkan derajat kesehatan para pekerja sehingga produktivitas kerja meningkat. Dalam Undang-Undang Republik Indonesia Nomor 36 Tahun 2009 Tentang Kesehatan, upaya kesehatan kerja ditunjukkan untuk melindungi pekerja agar hidup sehat dan terbebas dari gangguan kesehatan serta pengaruh buruk yang diakibatkan oleh pekerjaan sehingga sudah seharusnya pihak pengelola RS menerapkan upaya-upaya K3 di RS. K3 termasuk sebagai salah satu standar pelayanan yang dinilai di dalam akreditasi RS, disamping standar pelayanan lainnya.

Pekerja RS mempunyai risiko lebih tinggi dibanding pekerja industri lain untuk terjadinya Penyakit Akibat Kerja (PAK) dan KAK, sehingga perlu dibuat standar perlindungan bagi pekerja yang ada di RS. Untuk mencegah dan mengurangi resiko bahaya tersebut maka perlu ditetapkan standar K3 di RS. Perlunya pelaksanaan K3RS mengenai kebijakan pemerintah tentang RS di Indonesia adalah untuk meningkatkan akses, keterjangkauan, dan kualitas pelayanan kesehatan yang aman diRS. Perencanaan, pelaksanaan, 
monitoring, dan evaluasi K3 RS serta tindak lanjut, yang merujuk pada SK Menkes No. 432/ Menkes/ SK/ IV/ 2007 tentang Pedoman Manajemen K3 di RS dan OHSAS 18001 tentang Standar Sistem Manajemen K3. Sistem manajemen K3RS adalah bagian dari sistem manajemen RS.

\section{METODE}

metode yang digunakan dalam penulisan ini adalah metode kajian bebas dimana metode ini berwilayah lebih sempit dengan tingkat variasi yang rendah, namun dari penulisan ini dapat berkembang menjadi lebih luas. Metode kajian bebas ini merupakan metode yang dilakukan untuk melakukan penulisan yang dikumpulkan dari beberapa sumber seperti buku teks, buku referensi jurnal dan e-book, dan juga dibandingkan dengan jurnal yang berhubungan dengan "Hubungan Kebijakan K3 Dengan Keperawatan Di Indonesia”. Sehingga pembaca dapat mengerti informasi yang sudah ditulis dan dapat memahami pentingnya kebijakan K3RS dengan Keperawatan di Indonesia.

\section{HASIL}

mutu pelayanan RS, khususnya dalam hal kesehatan dan keselamatan bagi sumber daya manusia (SDM) RS, pasien, pengunjung/pengantar pasien, dan masyarakat sekitar RS. K3 termasuk sebagai salah satu standar pelayanan yang dinilai di dalam akreditasi RS, disamping standar pelayanan lainnya. Para pimpinan RS ditetapkan dan secara kolekif bertanggung jawab untuk menentukan misi RS dan membuat rencana dan kebijakan. Tanggung jawab dan akuntabilitas (badan) pengelola digambarkan di dalam peraturan internal (bylaws), kebijakan dan prosedur, atau dokumen serupa yang menjadi pedoman bagaimana tanggung jawab dan akuntabilitas dilaksanakan. Dalam pengaturan RS satu atau lebih individu yang kompeten mengatur tiap departemen / unit atau pelayanan di RS. Hal ini dapat digambarkan pada struktur organisasi, kebijakan, maupun prosedur yang berada di RS tersebut. Oleh karena itu para manajer memiliki kaitan langsung dengan kesehatan dan keselamatan kerja karena mereka memiliki kendali dan boleh memberikan instruksi.

RS dalam kegiatannya menyediakan fasilitas yang aman, berfungsi dan suportif bagi pasien, keluarga, staf, dan pengunjung. Secara fasilitas yang terkait tentang K3 yang diberikan RS sudah baik, akan tetapi fasilitas yang diberikan belum lengkap, fasilitas diberikan sesuai dengan anggaran RS tentang K3. Kebijakan yang berada di RS hanya baru kebijakan secara umum, sedangkan untuk kebijakan yang khusus 
untuk K3RS belum ada, akan tetapi secara pendanaan dari pihak manajemen sudah menyediakan anggaran untuk keperluan yang berkaitan dengan K3RS,dan fasilitas RS yang berkaitan dengan K3 sudah ada seperti : safety sign, APAR, dan APD. Untuk sistem keamanan tanggap darurat RS belum menggunakan alarm, alarm akan direalisasikan bersamaan dengan adanya K3RS. Hal ini dikarenakan RS masih baru sehingga dari manajemen RS masih berfokus pada penetapan kelas untuk RS. Fasilitas RS terkait K3 yang diberikan belum lengkap, fasilitas akan dilengkapi sesuai anggaran yang sudah dianggarkan untuk kegiatan yang berhubungan dengan K3.

Kebijakan K3 dibuat secara tertulis, tertanggal, ditandatangani oleh pengusaha atau pengurus RS, secara jelas menyatakan tujuan dan sasaran K3 serta komitmen terhadap peningkatan K3. Kebijakan K3 menjadi landasan utama yang diharapkan mampu menggerakkan semua elemen didalam perusahaan sehingga dapat terwujudnya program $\mathrm{K} 3$ dan program tersebut dapat dilaksanakan dengan baik. Komunikasi ini dilakukan agar seluruh karyawan dan pihak yang terlibat di RS mengetahui komitmen RS untuk menerapkan K3RS sehingga dapat terintergrasinya SMK3 didalam melaksanakan semua pekerjaannya. 
Tahapan-tahapan didalam penerapan K3RS di mulai dengan mengupayakan adanya :

\section{a. Kebijakan Manajemen Rumah Sakit}

Kebijakan manajemen rumah sakit harus sesuai dengan komitmen manajemen rumah sakit, kesadaran akan pentingnya K3RS dan keyakinan mendukung kualitas pelayanan rumah sakit. Kebijakan manajemen K3RS / safety and health policy berfokus pada penilaian kerja / operasional rumah sakit dan penerapan K3 semua organisasi di rumah sakit. Pelaksanaan K3RS meliputi standar kerja RS, standar keamanan bangunan, standar peralatan, standar pengendalian / kondisi emergensi, standar pengolahan limbah dan lingkungan.

Jadi, dalam penerapan kebijakan K3 di Rumah Sakit harus ada relevansi terhadap tugas perawat. Dimana relevansi kebijakan K3RS dengan tugas perawat ialah sebagai :

1. Pemberi asuhan keperawatan

2. Penyuluh dan konselor bagi klien

3. Pengelola pelayanan kesehatan

4. Peneliti keperawatan

5. Pelaksana tugas berdasarkan pelimpahan wewenang

6. Pelaksana tugas dalam keadaan keterbatasan tertentu

\section{b. Pengorganisasian K3 Rumah Sakit}

Pelaksanaan kebijakan K3 rumah sakit agar terlaksana dengan baik perlu dilakukan dalam bentuk organisasi dalam setiap rumah sakit dan memiliki kerja yang jelas serta adanya keterlibatan dna tingkatan komponen kerja di rumah sakit. Pengalaman menunjukkan suatu organisasi K3 tanpa program kerja yang jelas dan tidak didukung manajemen rumah sakit serta komponen kerja lainnya, akan merupakan kendalam di dalam penerapan K3RS. Organisasi K3 berada satu tingkat di bawah direktur dan bukan merupakan kerja rangkap. Adapun pengorgasisasian K3RS ada beberapa model yang pertama organisasi yang terstruktur dan bertanggung jawab kepada direktur rumah sakit. Bentuk organisasi K3 di rumah sakit merupakan organisasi struktural yang terintegrasi ke dalam komite yang ada di rumah sakit dan disesuaikan dengan kondisi/kelas masing-masing rumah sakit, misalnya komite medis/nosokomial kemudian yang kedua organisasi fungsional (non struktural), bertanggung jawab langsung ke direktur rumah sakit. Nama organisasinya adalah unit pelaksana K3 RS, yang dibantu oleh unit K3 yang beranggotakan seluruh unit kerja di rumah sakit. 


\section{c. Perencanaan dan Penerapan K3RS}

Penerapan K3RS meliputi identifikasi faktor bahaya dan resiko yang diakibatkannya (Hazard identification and risk assessment) dan menentukan prioritas faktor bahaya serta mengurangi resiko bahaya yang ditimbulkan identifikasi faktor bahaya dan pengendaliannya sangat menentukan keberhasilan organisasi K3.

Untuk melaksanakan komitmen dan kebijakan K3 rumah sakit, perlu disusun strategi antara lain:

- Advokasi sosialisasi program K3 rumah sakit

- Menetapkan tujuan yang jelas

- Organisasi dan penugasan yang jelas

- Meningkatkan SDM profesional di bidang K3 rumah sakit pada setiapunit kerja di lingkungan rumah sakit

- Sumber daya yang harus didukung oleh manajemen puncak

- Kajian resiko secara kualitatif dan kuantitatif

- Membuat program kerja K3 rumah sakit yang mengutamakan upaya peningkatan dan pencegahan

- Monitoring dan evaluasi secara internal dan eksternal secara berkala

- Perencanaan

\section{PENUTUP}

penerapan K3RS secara keseluruhan melibatkan perawat dalam meningkatkan kualitas keamanan dan kenyamanan pasien selama di rawat di Rumah Sakit. Penerapan K3RS tentunya ditetapkan kebijakan oleh pihak Rumah Sakit sesuai dengan peraturan perundang undangan yang berlaku. Perlu adanya penyampaian informasi informasi terkini yang harus diketahui perawat dalam mengendalikan keselamatan pasien dengan semakin tingginya kemajuan teknologi saat ini. Informasi ini perlu juga diikutkan dengan pelatihan pelatihan agar penerapannya benar benar mampu dilaksanakan oleh perawat selama memberikan asuhan keperawatan kepada pasien

\section{DAFTAR PUSTAKA}

Bando, J. J., Kawatu, P. A., \& Ratag, B. T. (2020). Gambaran Penerapan Program Keselamatan Dan Kesehatan Kerja Rumah Sakit (K3rs) Di Rumah Sakit Advent

Manado. KESMAS, 9(2).

Hafizurrachman, H. M. (2012). Kebijakan Keperawatan Berbasis Kinerja di RSU Tangerang. Jurnal 
Manajemen Pelayanan

Kesehatan, 15(01).

Ivana, A., Widjasena, B., \& Jayanti, S. (2014). Analisa Komitmen Manajemen Rumah Sakit (RS) terhadap Keselamatan dan Kesehatan Kerja (K3) pada RS Prima Medika Pemalang. Jurnal Kesehatan Masyarakat (e-Journal), 2(1), 35-41.

Lasut, D. S. A., Kawatu, P. A., \& Akili, R. H. (2019). ANALISIS PELAKSANAAN

STANDAR PELAYANAN KESELAMATAN DAN KESEHATAN KERJA RUMAH SAKIT (K3RS) DI RUMAH SAKITUMUM DAERAH NOONGAN KABUPATEN

MINAHASA. KESMAS, 8(7).

Maharani, D. P., \& Wahyuningsih, A. S. (2017). Pengetahuan, Sikap, Kebijakan K3 Dengan Penggunaan Alat Pelindung Diri Di Bagian Ring Spinning Unit 1.JHE (Journal of Health Education), 2(1), 3338.

Maringka, F., Kawatu, P. A., \& Punuh, M. I. (2019). Analisis pelaksanaan program kesehatan dan keselamatan kerja rumah sakit (K3RS) di Rumah Sakit Tingkat II Robert Wolter Mongisidi Kota Manado. KESMAS, 8(5), $1-10$.

Purba, H. I. D., Girsang, V. I., \& Malay, U. S. (2018). STUDI KEBIJAKAN, PERENCANAAN DAN PELAKSANAAN

KESELAMATAN DAN KESEHATAN KERJA RUMAH SAKIT (K3RS) DI RUMAH SAKIT UMUM (RSU) MITRA SEJATI MEDAN TAHUN 2018. Jurnal Mutiara Kesehatan Masyarakat,3(2), 113-124.

Simamora, R. H. (2018). Buku ajar keselamatan pasien melalui timbang terima pasien berbasis komunikasi efektif: SBAR. Medan: USUpress.

Simamora, R. H. (2019). Buku ajar pelaksanaan identifikasi pasien. Uwais Inspirasi Indonesia.

Siregar, K. N., Wahyuni, W., \& Nasution, R. M. (2019). Penetapan 
Kebijakan K3, Perencanaan

K3 dan Implikasinya terhadap

Kejadian Kecelakaan Kerja di

PKS Kebun Rambutan PTPN-

III Tebing Tinggi. Jurnal

Kesehatan Global, 2(1), 1-7.

Yunita, A. R., Sriatmi, A., \& Fatmasari, E. Y. (2016). Analisis faktorfaktor kebijakan dalam implementasi program keselamatan dan kesehatan kerja rumah sakit (k3rs) di instalasi gawat darurat rumah sakit umum daerah kota
Semarang. Jurnal Kesehatan Masyarakat (e-Journal), 4(2), 1-9.

Zulyanti, N. R. (2013). Komitmen Kebijakan Keselamatan Dan Kesehatan Kerja (K3) Sebagai Upaya Perlindungan Terhadap Tenaga Kerja (Sudi pada Mitra Produksi Sigaret (MPS) KUD Tani Mulyo Lamongan). Dia: Jurnal Administrasi Publik, 11(2). 